\title{
Environment
}

\section{Bankers under pressure}

\section{Washington}

IN an unusual alliance between Congress and the administration, the US Senate and the Treasury Department are together pressurizing the multinational development banks to improve environmental safeguards for their loan programmes to developing countries by, for example, "improving organizational capacity" and "more stringently conditional" loan disbursement. The banks are also criticized for their reluctance to discuss their efforts in this area with environmentalist groups in the United States and in the countries concerned.

The good intentions of the banks are not in question, but environmental organizations have successfully persuaded Congress and the Treasury that guidelines set by the banks are often not being properly followed, resulting in massive damage. Congress, in the shape of Senator Robert Kasten's (Republican, Wisconsin) foreign operations appropriations subcommittee, is determined that the banks should make "institutional changes" in their organizations to prevent disasters such as the Polonoreste project, a $\$ 434$ million loan by the World Bank to build a road through the Amazon rain forest of Brazil that caused massive deforestation of an area the size of Italy. The project was halted earlier this year as a result of continuous campaigning by environmental groups and subsequent congressional pressure, but Kasten fears that there are other projects where there is a "blatant disregard" for environmental protection and "insensitivity to native peoples"

One such project is the Narmada river basin dam in India, to be financed by the World Bank. Inadequate resettlement plans for more than a million people from 250 villages and the bureaucracy of state government has caused bitterness and "does not inspire optimism" in the bank, says David Maybury-Lewis, professor of anthropology at Harvard University. Maybury-Lewis singles out projects in $\mathrm{Pa}$ raguay and the Philippines as evidence for "bitter and pauperizing consequences of bank-financed relocation" and attacks the bank's recent agreement to finance a huge Indonesian transmigration scheme.

Kasten's subcommittee, which oversees funding of the development banks, last year instructed the World Bank to provide a high-level environmental review, to stop funding large-scale capital-intensive projects and instead to finance small-scale environmentally beneficial schemes and to ensure that non-governmental groups in the countries involved are consulted. The Treasury, directed to work with the bank. called progress since then "modest" at recent hearings of the subcommittee; the World Bank has not publicly responded to any of last year's requests.
Therefore, Kasten is likely to introduce "very strong language" into the appropriation for the next fiscal year. One possibility is that the US directors of the bank will be asked to hold a special board meeting and report to Congress on what actions they are taking to ensure that their environmental guidelines are being met.

The World Bank spent $\$ 800$ million last fiscal year (5 per cent of its total lending) on environmental projects, mainly improving water supplies, sanitation and reforestation schemes. The bank provided a detailed discussion of environmental

\section{EEC chemicals}

\section{Controversy over controls}

Brussels

Difficun:T discussions on controversial EEC legislation designed to tighten up controls on trade in dangerous substances with countries outside the European Community have reached an impasse at departmental level. The problem is now to be left to the 14 members of the European Commission when they meet in October in the hope that European Commissioners might achieve what plain reasoning has obviously not.

Until now, there have been no legal restrictions on EEC companies that wish to export to the developing countries chemicals whose use is restricted or banned in the Community. But a new and very unofficial EEC proposal would require that before being able to export certain pesticides and other potentially dangerous substances (such as polychiorinated biphenyls, polychloroterphenyls and asbestos), exporters would have to notify the government of the importing country and inform it of the hazardous status of the substance and the dangers involved in its use. The government would then have up to ninety days to refuse import permission.

Export authorization would be granted by the European Commission for a six month renewable period for a specific volume only. Subsequent exports would have to receive the approval of the designated authority set up by the EEC in each of the member states to keep an eye on trade in dangerous substances. Each ship ment would also have to carry details about the toxicity and risks of the product.

Not surprisingly, the proposals are strongly contested by those with industrial interests. Among the objections raised is the likely impracticability of the scheme in developing countries which often lack the administrative infrastructure necessary to respond within the given time. Industrialists fear that the only result will be a 90 day delivery penalty for EEC-based exporters, who would face unfair competi- issues in its annual report as evidence for its "great concern" about the detrimental impact of some projects. Bruce Rich of the Natural Resources Development Organization said that although the bank describes the problems well, it does not say how it is going to avoid contributing further to them.

The bank is unlikely to be able to maintain its aloof stance from its critics for very much longer. Although more than 100 countries own the bank, the United States is the single largest shareholder and can exert "considerable leverage" on the bank. Specific projects may soon be under more severe public scrutiny before development banks can provide the capital to implement them.

Maxine Clarke tion and suffer a loss of markets to nonEEC companies (in countries such as Switzerland) out of range of such laws.

If adopted, the EEC proposal would constitute a volte-face on the part of the Commission. Despite pressure two years ago from the Dutch and Greek environment ministers, the then Environment Commissioner, Karl-Heinz Narjes, who now has the industry portfolio, tried to put the lid on the debate by insisting that restrictions have been urged from the European Parliament, countries within the Community, and from further afield.

Notification and information procedures have already been adopted by the Organization for Economic Cooperation and Development and the United Nations Environmental Program but these involve prior notification, not the more far reaching concept of prior consent. (The current EEC draft proposal gets halfway there by suggesting a system of prior refusal.) The Food and Agricultural Organization's code of conduct for pesticides, which comes up for adoption in November, originally contained the notion of prior informed consent but has since been watered down

Even though the EEC proposal goes further than anything adopted to date by other international fora, if adopted in its present form it would not be going far enough for a coalition of international non-governmental organjzations known as 'CADE' (Coalition Against Dangerous Exports). Last week CADE published a report detailing the impact on developing countries of the double standards practised by the European Community. It reveals, for example, a current bid for tenders under the European Development Fund for companies prepared to export 40,000 litres of endrin and 60,000 kilograms of aldrin (both very dangerous pesticides) for application on a coffee plantation on the Ivory Coast. The Community debate in coming months promises to be a hot one. 